\title{
Can the protozoan parasite Bonamia ostreae infect larvae of flat oysters Ostrea edulis?
}

\author{
Isabelle Arzul ${ }^{a,{ }^{*}}$, Aimé Langlade ${ }^{b}$, Bruno Chollet $^{a}$, Maeva Robert ${ }^{a}$, Sylvie Ferrand ${ }^{a}$, \\ Emmanuelle Omnes ${ }^{a}$, Sophie Lerond ${ }^{a}$, Yann Couraleau ${ }^{a}$, Jean-Pierre Joly ${ }^{a}$, Cyrille François ${ }^{a}$, \\ Céline Garcia ${ }^{a}$ \\ a Institut Français de Recherche pour l'Exploitation de la Mer (IFREMER); Laboratoire de Génétique et \\ Pathologie (LGP); av de Mus de Loup, 17390 La Tremblade, France \\ ${ }^{\mathrm{b}}$ Institut Français de Recherche pour l'Exploitation de la Mer (IFREMER); Laboratoire Environnement \\ Ressource/Morbihan Pays de Loire, 12 rue des Résistants, BP 26, 56470 La Trinité-sur-Mer, France
}

* Corresponding author : I. Arzul, Tel: +33 5467626 10; Fax: +33 5467626 11, email address: Isabelle.Arzul@ifremer.fr

\begin{abstract}
:
Bonamia ostreae is an intracellular protistan parasite affecting flat oysters Ostrea edulis. It can be detected in juveniles but mortalities mainly affect oysters which are more than 2 years old. The parasite is usually observed inside haemocytes and sometimes free, notably in gill epithelia suggesting a parasite release through this organ. However, the infective form and ways of entry and release remain undetermined. Flat oysters incubate their larvae in their pallial cavity for 8-10 days before releasing them into the water column. Flat oysters in Bay of Quiberon in South Brittany (France) are known to be infected with $B$. ostreae since 1979 and is the most important area in France for $O$. edulis spat collection. Flat oysters incubating larvae were sampled in this area during summertime between 2007 and 2009. Both adults and larvae were preserved and assayed by PCR and in situ hybridisation (ISH). PCR tests revealed the presence of parasite DNA in some adults and larvae. Specific labelling could be detected by ISH in gills, digestive system, gonad and mantle in adults and in the epithelium surrounding the visceral cavity of some larvae. Our results demonstrate that larvae can be infected with $B$. ostreae. Larvae might thus contribute to the spread of the parasite during their planktonic life. In addition, their transfer for aquaculture purpose should be controlled especially when they are exported from infected zones.
\end{abstract}

Keywords: Bonamia ostreae; Flat oyster; Ostrea edulis; Transmission; Larvae; Parasite life cycle 


\section{Introduction}

The flat oyster Ostrea edulis is a native species from Europe. It occurs along the western European coast from Norway to Morocco, through the Mediterranean Sea, and into the Black Sea. Naturalized populations also occur along the eastern coast of North America from Maine to Rhode Island following intentional introductions in the 1940s and 1950s (Hidu \& Lavoie, 1991; MacKenzie et al. 1997). This species has been endangered by overfishing, cold winters, predation pressure and diseases and is today in the OSPAR (Oslo and Paris Conventions for the protection of the marine environment of the North-East Atlantic) list of threatened and/or declining species and habitats (OSPAR agreement 2008-6). Specifically, French flat oyster production estimated at 28000 tonnes in 1960 dramatically decreased because of two protozoan diseases namely marteiliosis due to Marteilia refringens and bonamiosis due to Bonamia ostreae (Meuriot \& Grizel, 1984; Goulletquer \& Héral, 1997). The production of this endemic species has remained low, less than 2000 tonnes per year since the emergence of these two diseases and is now located in a few specific areas (Figure 1). Data from the last census on shellfish culture in France carried out in 2001 showed that most of the spat is collected in the Bay of Quiberon and to a lesser extent in the Bay of Brest (Girard et al. 2005). Spat collected in the Bay of Brest and some of the spat collected in the Bay of Quiberon are moved to Cancale, North Brittany for grow-out when the spat is 10 months old. In 2001, the production of flat oysters was estimated at 1960 tonnes (FAO, 2008).

71 Few data are available on pathogens affecting young flat oysters. However, herpes-like viruses were reported in 5-month-old spats collected in northern Brittany (Comps \& Cochennec, 1993). Similar viruses were associated with the mortality of flat oyster larvae in a hatchery (Renault et al. 2000, Arzul et al. 2001). Vibrio strains were shown to be pathogenic 
to larvae of flat oysters by inducing mortalities in hatcheries (Jeffries, 1982; DiSalvo et al. 1978; Tubiash et al. 1965). Young prespawning flat oysters (1-3 month old to 18 month-old) are susceptible to infection by $B$. ostreae and can develop a high prevalence and intensity of infection over a six-month period (Lynch et al. 2005). Mortality associated with infection with B. ostreae has even been described in 6 month-old juveniles (Lallias et al. 2008). However, individuals older than 2 years appear more susceptible to the disease (Balouet et al. 1983; Cullotty \& Mulcahy, 1996; Grizel, 1985; Robert et al. 1991) and death usually occurs concurrently with the highest level of infection intensity (Bréhelin et al. 1982; CaceresMartinez et al. 1995; Montes et al. 2003). While adults and juveniles are known to be susceptible stages to bonamiosis there is no data on the possible role of larvae in the cycle of the parasite.

Bonamia ostreae life cycle is unknown, but the disease can be transmitted directly between oysters in a population or experimentally by cohabitation or inoculation (Elston et al. 1986, Hervio et al. 1995), suggesting that an intermediate host is not required for the parasite to complete its life cycle. Observation of free parasites in gill epithelia potentially associated with gill lesions supports the hypothesis of a parasite release through this organ (Montes et al. 1994). However, the infective form and routes of entry and release remain undetermined. A controversial description proposed that B. ostreae was an ovarian tissue parasite for part of its life cycle (Van Banning, 1990) but this hypothesis was not confirmed. In spite of several management practices, diseases have drastically affected wild and cultured flat oyster populations. The main solutions for the industry rely on transfer restrictions and on the development of resistant strains which require a better understanding of host pathogen interactions.

The Bay of Quiberon, South Brittany, France (Figure 1) is an interesting site to study bonamiosis in flat oyster populations because flat oysters there have been infected since 1979 
with prevalence of infection ranging from 2 to $37 \%$ and a mean around $13 \%$ (Arzul et al.

101 2006). In addition, it is the most important bay for flat oyster spat collection in France and surveys on the reproduction of this species have been carried out there since 1996. Flat oyster

103 female gametes are liberated into the pallial cavity where they are fertilized by externally

104 released sperm. After an incubation period of 8-10 days, larvae (160 $\mu \mathrm{m}$ in size) spend 8 to 10

105 days as a pelagic stage before settlement. The survey of flat oyster reproduction in the Bay of

106 Quiberon aims at following the status of spawners to determine the presence of gametes and 107 larvae in the oysters and the presence of larvae in the water column in order to advise farmers 108 about the most suitable period for spat collection. In the context of this survey, some adults 109 incubating larvae in their pallial cavity were selected in 2007, 2008 and 2009, and were tested

110 for the presence of the parasite B. ostreae. The detection of the parasite in adults and juveniles 111 raises the question about the transmission of the parasite from spawners to larvae as well as 112 the role played by larvae in the disease spread.

\section{Materials and methods}

\subsection{Study site}

118 The Bay of Quiberon is an open bay located in southern Brittany (Figure 1). This bay has an 119 area of 2873 ha and presents suitable conditions for oyster production: depth between 3 and

$12010 \mathrm{~m}$ allowing mitigation of swell effect and dredge use for harvesting; good water mass

121 renewal (SHOM 1968); fertilization by close rivers (Loire and Vilaine); protection by

122 Quiberon peninsula and good sediment composition (sand and mud). Eighty three oyster 123 farms are located in this bay (Mazurié et al. 2002). Most of these farms produce the Pacific 124 cupped oyster Crassostrea gigas. However, shallow sites in the North and West of the Bay 125 are dedicated to flat oyster spat collection on mussel shells or on limed plates. Twenty two 
oyster farms collect the spat of Ostrea edulis and about 12 of them grow-out flat oyster for marketing.

\subsection{Flat oyster sampling}

Spawners were collected weekly by diving between the end of April and the end of August. Spawners were then opened and oysters incubating larvae (Figure 2) were selected for our study. Thirty one, 53 and 36 oysters were found incubating larvae in 2007, 2008 and 2009 respectively.

A section of tissue from each adult oyster was fixed in Davidson's fixative for histology and in situ hybridisation tests and a piece from gills was also fixed in $100 \%$ ethanol for DNA extraction. Incubated larvae from each adult oyster were transferred in separate tubes and some were fixed in $100 \%$ ethanol for DNA extraction while the remainder were preserved in Davidson's fixative for in situ hybridisation tests. Prior to DNA extraction, larvae were rinsed once in 1X PBS (150 mM NaCl, $12.5 \mathrm{mM} \mathrm{Na}_{2} \mathrm{HPO}_{4}, 3 \mathrm{mM} \mathrm{KH} \mathrm{HPO}_{4}, \mathrm{pH}$ 7.5).

\subsection{DNA extraction}

Twenty five mg of gill tissue or larvae were collected from each adult for DNA extraction using the QIAamp DNA minikit (Qiagen) according to the manufacturer's instructions. DNA was eluted and resuspended in a final volume of $50 \mu 1$ of sterile deionised water and then diluted at a final concentration of $100 \mathrm{ng} / \mu 1$.

\subsection{PCR conditions and parasite species determination by RFLP and sequencing}

Conventional PCR was performed according to Cochennec et al. (2000). PCR reactions were carried out in a final volume of $50 \mu \mathrm{l}$. Between 50 and $100 \mathrm{ng}$ of extracted DNA were added to $49 \mu 1$ of PCR mixture containing buffer $\left(500 \mathrm{mM} \mathrm{KCl}, 100 \mathrm{mM}\right.$ Tris/ $\mathrm{HCl}\left[\mathrm{pH} 9.0\right.$ at $25^{\circ} \mathrm{C}$ ] 
and 1\% Triton $\left.{ }^{\circledR} \mathrm{X}-100\right), 2.5 \mathrm{mM} \mathrm{MgCl} 2,0.2 \mathrm{mM}$ dNTP mix, $1 \mu \mathrm{M}$ forward (Bo) and reverse

157 (Boas) primers and 0.02 units/ $\mu 1$ Taq DNA polymerase (Goldstar Eurogentec). Amplification

158 programme was as follows : initial denaturation for 5 min at $94^{\circ} \mathrm{C} ; 30$ cycles of 1 min at $94^{\circ} \mathrm{C}, 1 \mathrm{~min}$ at $55^{\circ} \mathrm{C}, 1 \mathrm{~min}$ at $72^{\circ} \mathrm{C}$ and a final extension of $10 \mathrm{~min}$ at $72^{\circ} \mathrm{C}$.

160 Parasite species was subsequently determined by restriction fragment length polymorphism

161 (RFLP) analysis (Cochennec et al. 2003; Hine et al. 2001) performed by separate digestions

162 of $10 \mu 1$ of PCR products with BglI and HaeII (Promega). The resulting fragment patterns

163 were analysed electrophoretically on $2 \%$ agarose gel.

164 Some PCR products were cloned using the TOPO TA cloning kit (Invitrogen) according to manufacturer's recommendations and positive clones were then selected for plasmid DNA purification by FastPlasmid ${ }^{\circledR}$ Min (Ependorf). Some plasmidic DNA suspensions were sequenced bidirectionally using the Big Dye V3 sequencing kit (Applied Biosystem) and Bo and Boas primers. Obtained sequences were compared with those included in GenBank using BLAST algorithm (Atschul et al. 1997).

170

171

\subsection{Histology and in situ hybridisation}

After 48 hours of fixation in Davidson's fixative, tissue were maintained in $70 \%$ ethanol until dehydration and embedding in paraffin for histology according to standard procedures. Larval samples were treated similarly to adults but in small plastic tubes. Paraffin blocks were cut in 2-3 $\mu \mathrm{m}$ sections and stained by hematoxylin and eosin. In situ hybridisation was performed on $5 \mu \mathrm{m}$ thick sections on aminoalkylsilane coated slides (Silane-Prep Slides, Sigma). The probe was labelled by means of digoxigenin incorporation to the PCR reaction mix. PCR was performed as described above, except that $2.5 \mu 1$ of DIG-dUTP $25 \mathrm{mM}$ (Roche) were added to the mix. In situ hybridisation was performed following procedures previously published 
181 (Cochennec et al. 2000) and using non infected oysters Ostrea edulis as negative controls and

182 Ostrea edulis infected with B. ostreae as positive controls.

183

184

185

186

187

188

189

190

191

192

193

194

195

196

197

\section{Results}

\subsection{Detection by PCR and species characterization of Bonamia sp.}

In 2007, four of the 31 tested adults yielded positive signal by PCR. One of the 31 related larvae samples appeared positive by PCR and it corresponded to one of the positive adult oyster. In 2008, of the 53 tested samples, 13 adults and 9 samples of larvae were found positive by PCR. Three of the spawners detected positive had positive signal in their corresponding larvae samples. In 2009, 8 of 36 adults and 5 of 36 samples of larvae were detected positive by PCR. All 5 positive larval samples corresponded to positive adult oysters. PCR products were tested by RFLP and all the obtained restriction profiles were identical to B. ostreae except for one sample of larvae collected in 2008 which exhibited Bonamia exitiosa like profiles (Figure 3).

Six PCR products showing B. ostreae RFLP profiles and the one showing the B. exitiosa profile were cloned. A total of 40 clones were tested again by PCR-RFLP to check the potential presence of both parasite species in the same sample. Larval samples which gave $B$. exitiosa profiles by direct PCR-RFLP analysis gave only B. exitiosa profiles for the 4 tested clones. The other PCR products only yielded B. ostreae profiles.

One clone (a) showing B. ostreae profile and two clones (b and c) showing B. exitiosa profiles were selected for sequencing. Sequencing confirmed the RFLP results: obtained sequences showed (a) 3 transitions and 99\% of identity compared with B. ostreae (AF192759.1) and (b and c) $100 \%$ of identity with B. exitiosa (F337563.1). 
210 In adults, histology revealed the presence of Bonamia parasites in $2(6 \%), 9(17 \%)$ and 4 211 (11\%) of the examined flat oysters in 2007, 2008 and 2009 respectively (Table 2). Seventy 212 three percent of these 15 oysters were also found positive by PCR. By histology, infection 213 level was generally low (few infected zones and few parasite cells observed per infected area) 214 and the parasite was mainly detected in haemocytes in the connective tissue of the digestive system, gonad and gills (Figures 4a, b, c and d). Infection with the parasite was generally associated with haemocyte infiltration. However, haemocyte infiltration was observed in many tested oysters, from 55\% in 2008 up to $65 \%$ in 2007.

218 Histological examination also revealed the presence of other microorganisms commonly 219 observed in flat oysters including Mytilicola, ciliates, turbellaria and rickettsia-like organisms (Table 2). Haemocytic neoplasia and abnormal nuclear shapes were observed in 1 and 3 oysters collected in 2009, respectively (Table 2).

\subsection{In situ hybridisation (ISH)}

224 ISH tests were performed on adult and larval samples found positive for B. ostreae by PCR. In 2007, only adult oysters could be tested by ISH since larvae were not fixed for that purpose.

Thirty one adults detected positive by PCR and/or histology were tested by ISH and positive

228 signal was observed in 13 of them. The parasite was mainly detected in the gills (in 8 out of 229 the 13 positive oysters), in the gonad (in 7 out of the 13 positive oysters), in the digestive system (in 6 out of the 13 positive oysters) and in the mantle (in 2 out of the 13 positive oysters). In gills and digestive system, the parasite was detected in haemocytes in the connective tissue (Figure 5a) and extracellularly in the epithelium. In the gonad, the parasite 
was mainly detected in haemocytes inside the lumen of gonadal follicles (Figure 5b ; Table

234 3). In three adults, some larvae present in the sections appeared positive.

235 Fourteen pools of larvae detected positive in PCR and histology were tested by ISH and 7

236 gave positive signals. The parasite was essentially observed in the epithelium surrounding the 237 visceral cavity (Figures 6a, b and c).

\section{Discussion}

Bonamia ostreae is an intracellular protozoan affecting flat oysters Ostrea edulis. Despite more than 30 years of research, its complete life cycle remains unsolved and several characteristics of the disease are not understood. In particular, the routes of entry and release of the parasite from its host are undetermined. Parasite release could take place in gills as supported by observation of free parasites in this organ (Montes et al. 1994). Moreover, Van Banning (1990) suggested that B. ostreae was an ovarian tissue parasite for part of its life cycle but this hypothesis has not been confirmed. While adults and juveniles are known to be susceptible stages to bonamiosis, the possible role of larvae in the cycle of the parasite was unknown.

We took advantage of a survey on flat oyster reproduction in the Bay of Quiberon, the most important French area for spat collection of flat oyster, which is also known to be endemic for B. ostreae since 1979. In the frame of this survey, oysters incubating larvae were sampled for subsequent analyses to test the presence of the parasite in spawners and in their progeny.

During the three years of the study, adults (between 13 and 25\%) were found positive by PCR more frequently than larval samples (between 3 and 17\%). Thirty six percent of adults found positive by PCR had their corresponding pool of larvae positive. All the PCR positive samples appeared infected with $B$. ostreae except one larval sample found infected with $B$. 
exitiosa. Bonamia exitiosa and B. ostreae are very similar morphologically and their

262 differential diagnostic is very difficult based on histological examination. PCR-RFLP and sequencing are necessary to characterize these parasites at the species level. In October 2007,

B. exitiosa was reported for the first time in flat oyster Ostrea edulis in Europe, more precisely in Galicia, Spain (Abollo et al. 2008). It was then reported in Italy along the Adriatic coast (Narcisi et al. 2010) and in France in the Mediterranean Sea. The positive result obtained in one larvae sample in the Bay of Quiberon in 2008 is the only detection of $B$. exitiosa DNA on the French Atlantic coast. More samples should be tested to determine the prevalence of this parasite in Quiberon bay.

As expected, histology appeared less sensitive than PCR but depicted the distribution of the parasite inside the oyster and revealed the presence of other pathogens and associated lesions.

272 Infection level was low and B. ostreae was mainly detected in haemocytes in the digestive system, gonad and gills. Haemocyte infiltration was observed in many tested oysters and not only in Bonamia infected oysters. Adult oysters and larvae found positive by PCR were also tested by in situ hybridisation. In adult oysters, the parasite was detected, in descending 276 detection frequency, in the gills, gonad, digestive system and in the mantle. It was observed 277 inside haemocytes in connective tissues and in gonadal follicles or extracellularly in the epithelia of the gills and the digestive system.

279 Flat oysters tested in our study were male (53\%) or hermaphrodite (47\%). The larviparous 280 oysters of the genus Ostrea including O. edulis undergo rhythmical changes in sexuality, the 281 initial phase in these species is usually male, followed by alternating female and male phases 282 (Orton, 1927). This feature explains why in our study, incubating oysters were male or 283 hermaphrodite. The adult broods their larvae inside the pallial cavity. In the congeneric species $O$. chilensis, the embryos are also brooded in the pallial cavity of the parent oyster, 
maternal demibranchs, passing along the food grooves and aggregating in the region of the labial palps (Chaparro et al., 1993). In our study, seven pools of larvae presented positive signal by in situ hybridisation. In addition, three larvae present in sections of infected adults were found infected using this technique. In positive larvae, the parasite is located in the epithelia surrounding the visceral cavity. This location suggests that larvae become infected through the ingestion of parasites. In $O$. chilensis, it has been shown that larvae are able to remove suspended particles, between 2 and $10 \mu \mathrm{m}$ in diameter, from the pallial cavity of the brooding adult and ingest them (Chaparro et al. 1993).

The results of in situ hybridisation demonstrated that larvae of $O$. edulis can be infected with B. ostreae and that PCR positive results do not only correspond to the presence of DNA from dead parasites or from parasites attached to the surface of the larvae.

The detection of the parasite in adults and larvae raises, among others, the question about the transmission of the parasite from adults to larvae. The flat oyster $O$. edulis keeps eggs and then larvae for an incubation period of 8-10 days before releasing larvae into the water column (Marteil, 1960). This period of incubation might favour the transmission of the pathogens from the adult oyster to its progeny. A previous study carried out on $O$. edulis families suggested a significant influence of the Ostreid herpesvirus 1 infective status of the parents on the infection of the progeny and thus a possible vertical transmission of the virus . (da Silva et al. 2008). In our study, the level of infection in adult oysters was low which could explain the low level of infection observed in larvae by in situ hybridisation. Generally, few larvae were found positive and few parasites were detected in infected larvae.

The success of experimental transmission of the parasite between infected and non infected oysters demonstrates that direct transmission is possible through the water column and an intermediate host is not required for the parasite to complete its life cycle (Hervio et al. 1995). These results are supported by recent data showing that B. ostreae is able to survive in sea 
water for at least 1 week (Arzul et al. 2009) and can thus be efficiently transmitted through

312 the water.

313 However, it seems that B. ostreae is able to use additional routes of transmission. Lynch et al.

314 (2007) investigated the potential involvement of macroinvertebrate and zooplankton species

315 in the parasite life cycle and found that eight benthic macroinvertebrates and 19 grouped

316 zooplankton samples gave positive results by PCR. Certain species, found positive for the

317 parasite DNA, were then used in laboratory transmission trials, to investigate if they could

318 infect naïve oysters. Transmission of $B$. ostreae was effected to two naïve oysters cohabiting

319 with the brittle star, Ophiothrix fragilis (Lynch et al. 2006). Nevertheless, considering the

320 correlation between density of oysters and prevalence of bonamiosis (Grizel 1985, Hudson \&

321 Hill 1991), the parasite mainly depends on flat oysters $O$. edulis for its survival and spread,

322 and other aquatic organisms might not be involved as important carriers or transmitters (Van

323 Banning 1988). Therefore, transmission of $B$. ostreae between oysters probably mainly occurs

324 through the water column and larvae may contribute to facilitate the dispersal of the parasite

325 during their planktonic life and transport by the currents in the zone.

327 To conclude, positive results obtained by PCR and confirmed by in situ hybridisation are

328 indicative of an infection of adults but also of larvae by the parasite $B$. ostreae. For the first

329 time it is shown that B. ostreae is able to infect oyster larvae within the pallial cavity. These

330 results suggest that the parasite could be transmitted from adults to larvae during the period

331 of larval incubation. Larvae might thus contribute to spread the parasite during their

332 planktonic life. In addition, the transfer of all life stages of the oyster for aquaculture or

333 stock enhancement purpose should be controlled especially when they are exported from 334 infected zones. 
Aknowledgements: We acknowledge Dr. T. Renault for facilitating this work at the

338 Laboratory of Genetic and Pathology, Ifremer, La Tremblade. This work was supported by

339 EU DG Sanco through the Community Reference Laboratory for Mollusc Diseases, Ifremer,

340 La Tremblade. This study would not have been possible without the valuable contribution of

341 the consulting office "Cochet Environnement" and the South Brittany Regional Section of

342 oyster production which coordinate the study of the reproduction of flat oyster in Quiberon

343 Bay. We also thank Dr. R. Robert from Ifremer Argenton for sharing information on the 344 reproduction and ecophysiology of the flat oyster. Finally, we greatly acknowledge Dr. S.

345 Bower for valuable critical comments on the manuscript.

Abollo, E., Ramilo, A., Casas, S.M., Comesaña, P., Cao, A., Carballal, M.J., Villalba, A. 2008. First detection of the protozoan parasite Bonamia exitiosa (Haplosporidia) infecting flat oyster Ostrea edulis grown in European waters. Aquaculture. 274, 201-207.

Altschul, S.F., Madden, T.L., Schaffer, A.A., Zhang, J., Zhang, Z., Miller, W., Lipman, D.J. 1997. Gapped BLAST and PSI-BLAST: a new generation of protein data base search programs. Nucleic Acids Res. 25, 3389-3402.

Arzul, I., Renault, T. Lipart, C. 2001. Experimental herpes-like viral infections in marine bivalves : demonstration of interspecies transmission. Dis. Aquat. Organ. 46,1-6. and Ostrea edulis : a stable host-parasite system in France? In: Proceedings of the XIth 360 ISVEE conference, Cairns, Australia, 6-11 August 2006, p. 5.

361 Arzul, I., Gagnaire, B., Bond, C., Chollet, B., Morga, B., Ferrand, S., Robert, M.,Renault, T. 362 2009. Effects of temperature and salinity on the survival of Bonamia ostreae, a parasite infecting flat oysters Ostrea edulis. . Dis. Aquat. Organ. 85, 67-75 
364 Balouet, G., Poder, M., Cahour, A. 1983. Haemocytic parasitosis : morphology and pathology 365 of lesions in the French flat oyster, Ostrea edulis L. Aquaculture 34,1-14.

366 Bréhelin, M., Bonami, J.R., Cousserand, F., Vivares, C.P. 1982. Existence de formes 367 plasmodiales vraies chez Bonamia ostreae parasite de l'huître plate Ostrea edulis. R. Acad. 368 Sci. Paris, Ser. III. 295, 45-48.

369 Caceres-Martinez, J., Robledo, J.A.F., Figueras, A. 1995. Presence of Bonamia and its 370 relation to age, growth rates and gonadal development of the flat oyster, Ostrea edulis, in the 371 Ria de Vigo, Galicia (NW Spain). Aquaculture. 130, 15-23.

372 Chaparro, O.R., Thompson, R.J., Ward, J.E. 1993. In vivo observations of larval brooding in 373 the Chilean oyster, Ostrea chilensis (Philippi, 1845). Biol. Bull. 185, 365-372.

374 Cochennec, N., F. Le Roux, Berthe, F., Gérard, A. 2000. Detection of Bonamia ostreae based 375 on small subunit ribosomal probe. J. Invertebr. Pathol. 76, 26-32.

376 Cochennec, N., Reece, K.S., Berthe, F.C.J., Hine, P.M. 2003. Revisiting Mikrocytos roughleyi 377 taxonomic affiliation points to the genus Bonamia (Haplosporidia). Dis. Aquat. Org. 54, 209378217.

379 Comps, M., Cochennec, N. 1993. A Herpes-like virus from the European oyster Ostrea edulis 380 L. J. Invertebr. Pathol. 62, 201-203.

381 Culloty, S. C., Mulcahy, M.F. 1996. Season-, age-, and sex-related variation in the prevalence 382 of bonamiasis in flat oysters (Ostrea edulis L.) on the south coast of Ireland. Aquaculture 144, $383 \quad 53-63$.

384 da Silva, P.M., Renault, T., Fuentes, J., Villalba, A. 2008. Herpesvirus infection in European 385 flat oysters Ostrea edulis obtained from brood stocks of various geographic origins and grown 386 in Galicia (NW Spain). Dis. Aquat. Org. 78, 181-188.

387 DiSalvo, L.H., Blecka, J., Zebal, R. 1978. et al. 1978. Vibrio anguillarum and larval mortality 388 in a California coastal shellfish hatchery. Appl. Environ. Microbiol. 35, 219-221. 
389 Elston, R.A., Farley, C.A., Kent, M.L. 1986. Occurrence and significance of bonamiasis in

390 European flat oysters Ostrea edulis in North America. Dis. Aquat. Organ. 2,49-54

391 Food and Agriculture Organization of the United Nations (FAO) (2008) FishStat Plus -

392 Universal software for fishery statistical time series. Accessed 14 Sept. 2010

393 http://www.fao.org/fi/statist/FISOFT/FISHPLUS.asp

394 Girard, S., Pérez Agùndez, J.A., Miossec, L., Czerwinski, N. 2005. Recensement de le 395 Conchyliculture 2001, Agreste Cahier n²1, Ed. Ministère de l’Agriculture, de la Pêche et de la 396 Ruralité, 89 pp.

397 Goulletquer, P., Héral, M. 1997. Marine Molluscan Production Trends in France: From 398 Fisheries to Aquaculture. NOAA Tech. Rep. NMFS. 129, 137- 164.

399 Grizel, H. 1985. Etudes des récentes épizooties de l'huître plate Ostrea edulis L. et de leur 400 impact sur l'ostréiculture bretonne. PhD dissertation, Université des Sciences et Techniques 401 de Languedoc, Montpellier, France

402 Hervio, D., Bachere, E., Boulo, V., Cochennec, N., Vuillemin, V., Le Coguic, Y., Cailletaux, 403 G., Mazurie, J., Mialhe, E. 1995. Establishment of an experimental infection protocol for the 404 flat oyster Ostrea edulis with the intrahaemocytic protozoan parasite Bonamia ostreae: 405 application in the selection of parasite-resistant oyster. Aquaculture 132,183-194

406 Hidu, H., Lavoie, R. 1991. The European oyster, Ostrea edulis L., in Maine and Eastern 407 Canada. In W. Menzel (ed.), Estuarine and Marine Bivalve Mollusk Culture, pp. 36-46 . 408 Menzel Edition, CRC Press, Boca Raton, Florida, USA.

409 Hine, P.M., Cochennec-Laureau, N., Berthe, F.C.J. 2001. Bonamia exitiosus n. sp. 410 (Haplosporidia) infecting flat oysters Ostrea chilensis (Philippi) in New Zealand. Dis. Aquat. 411 Org. 47, 63-72.

412 Hudson, E. B., Hill, B.J. 1991. Impact and spread of bonamiasis in the UK. Aquaculture 93, $413 \quad 279-285$. 
414 Jeffries, V.E. 1982. Three vibrios strains pathogenic to larvae of Crassostrea gigas and 415 Ostrea edulis. Aquaculture 29, 201-226.

416 Lallias, D., Arzul, I., Heurtebise, S., Ferrand, S., Chollet, B., Robert, M., Beaumont, A.R., 417 Boudry, P., Morga, B., Lapègue S. 2008. Bonamia ostreae-induced mortalities in one-year old 418 European flat oysters Ostrea edulis: experimental infection by cohabitation challenge. Aquat. 419 Living Resour. 21,423-439.

420 Lynch, S.A., Armitage, D.V., Wylde, S., Mulcahy, M.F., Culloty, S.C. 2005. The 421 susceptibility of young prespawning oysters, Ostrea edulis, to Bonamia ostreae. J. Shellfish 422 Res. $24,1019-1025$

423 Lynch, S. A., Armitage, D. V., Wylde, S., Mulcahy, M.F., Culloty, S.C. 2006. Inventory of 424 benthic macroinvertebrates and zooplankton in several European Bonamia ostreae-endemic 425 areas and their possible role in the life cycle of this parasite. Mar. Biol. 149, 1477-1487.

426 Lynch, S.A., Armitage, D.V., Coughlan, J., Mulcahy, M.F., Culloty, S.C. 2007. Investigating 427 the possible role of benthic macroinvertebrates and zooplankton in the life cycle of the 428 haplosporidian Bonamia ostreae. Exp. Parasitol. 115,359-368

429 MacKenzie, C.L. Jr., Burnell, V.G. Jr., Rosenfield, A., Hobart, W.L. (eds.). 1997. The history, 430 present condition, and future of molluscan fisheries of North and Central America and 431 Europe. US Dept of Commerce, NOAA Technical Reports 127(1):234 pp; 128(2):217 pp; 432 129(3):240 pp. NMFS, Washington DC, USA.

433 Marteil, L. 1960. Ecologie des huîtres du Morbihan Ostrea edulis Linné et Gryphea angulata 434 Lamarck. Rev. Trav. Inst. Pêches marit. 24, 329-446.

435 Mazurié, J., Foucart, M., Langlade, A., Bouget, J.F., Fleury, P.G., Joly, J.P., Martin, A.G. 436 2002. Analyse des pratiques, contraintes et performances d'élevage de l'huître creuse 437 Crassostrea gigas, en 2001, sur différentes concessions en eau profonde de la Baie de 
438 Quiberon : Enquête auprès de 18 concessionnaires et plongées sur 18 semis d'huîtres de 2 ans, 439 en juin et octobre 2001. Rapport Ifremer. DRV/RST/RA/LCB-2002-08, 62 pp.

440 Meuriot, E., Grizel, H. 1984. "Note sur l'impact économique des maladies de l'huître plate en

441 Bretagne." Rapport Technique I.S.T.P.M. 12: 19 pp.

442 Montes, J., Ferro Soto, B., Conchas, R.F., Guerra, A. 2003. Determining culture strategies in 443 populations of the European flat oyster, Ostrea edulis, affected by bonamiosis. Aquaculture $444220,175-182$.

445 Montes, J., Anadon, R., Azevedo, C. 1994. A possible life cycle for Bonamia ostreae on the 446 basis of electron microscopy studies. J. Invertebr. Pathol. 63,1-6

447 Narcisi, V., Arzul, I., Cargini, D., Mosca, F., Calzetta, A., Traversa, D., Robert, M., Joly, J. 448 P., Chollet, B., Renault, T., Tiscar, P. G. 2010. Detection of Bonamia ostreae and Bonamia 449 exitiosa (Haplosporidia) in Ostrea edulis from the Adriatic Sea (Italy). Dis. Aquat. Organ. 89, $450 \quad 79-85$

451 Orton, J.H. 1927. Observation experiments on sex-change in the European oyster (Ostrea 452 edulis). Part 1. The change from female to male. J. Mar. Biol. Assoc. U.K. 14, 967-1045.

453 OSPAR agreement 2008-6. Ospar convention for the protection of the marine environment of 454 the northeast Atlantic. www.ospar.org/html_documents/ospar/html/ospar_list_of_decsrecs.pdf 455 Accessed 20 Nov. 2010

456 Renault, T., Le Deuff, R.M., Chollet, B., Cochennec, N., Gérard, A. 2000. Concomitant 457 herpes-like virus infections among hatchery-reared larvae and nursery-cultured spat 458 Crassostrea gigas and Ostrea edulis. Dis. Aquat. Organ., 42,173-183.

459 Robert, R., Borel, M., Pichot, Y., Trut, G. 1991. Growth and mortality of the European oyster 460 Ostrea edulis in the Bay of Arcachon (France). Aquat. Living Resour. 4, 265-274.

461 SHOM (Service Hydrographique et Océnaographique de la Marine) 1968. Courants de marée 462 dans la Manche et sur des côtes françaises de l'Atlantique. SHOM, Paris, 245p. 
463 Tubiash, H.S., Chanley, P.E., Leifson, E. 1965. Bacillaris necrosis a disease of larval and 464 juvenile bivalve molluscs. I. Etiology and epizootiology. J. Bacteriol. 90,1036-1044.

465 Van Banning, P. 1988. Management strategies to control diseases in the Dutch culture of 466 edible oysters. In: Fisher WS (ed), Disease Processes in Marine Bivalve Molluscs. American 467 fisheries Society, Spec Publ 18,243-245

468 Van Banning, P. 1990. The life cycle of the oyster pathogen Bonamia ostreae with a 469 presumptive phase in the ovarian tissue of the European flat oyster, Ostrea edulis. 470 Aquaculture 84, 189-192.

471

472 


\section{TABLES}

\begin{tabular}{lllll}
\hline Year & Positive Adults & Positive pools of larvae & Adult/Larvae & Total \\
\hline 2007 & 4 & 1 & 1 & 31 \\
2008 & 13 & 9 & 3 & 53 \\
2009 & 8 & 5 & 5 & 36 \\
\hline
\end{tabular}

Table 1- Results of PCR for adults and pools of larvae tested in 2007, 2008 and 2009 for the

477 presence of Bonamia parasite. The number of adult oysters for which the corresponding pools 478 of larvae were found positive by PCR is indicated in the column "Adult/Larvae". The total 479 number of tested samples is reported in the last column.

480

\begin{tabular}{lccc}
\hline Year & 2007 & 2008 & 2009 \\
& $N=31$ & $N=53$ & $N=36$ \\
& 2 & 9 & 4 \\
\hline Bonamia spp. & 20 & 29 & 23 \\
Haemocyte infiltration & 1 & 3 & \\
Mytilicola spp. & 4 & 1 & 2 \\
Ciliates & 1 & & 1 \\
Rickettsia-like organisms & 1 & 5 & 3 \\
Necrosis of digestive epithelia & 1 & & \\
Turbellaria & & 1 & 3 \\
Atrophy of digestive diverticula & & & 1 \\
Abnormal nuclear shapes & & & \\
Haemocytic neoplasia & &
\end{tabular}

482 Table 2- Observation by histology of pathological conditions in flat oysters Ostrea edulis 483 incubating larvae. 


\begin{tabular}{|c|c|c|c|}
\hline \multirow{2}{*}{ Gills } & \multirow{2}{*}{8} & Connective tissue (IH) & 6 \\
\hline & & Epithelium (EC) & 5 \\
\hline \multirow{2}{*}{ Mantle } & \multirow{2}{*}{2} & Connective tissue (IH) & 2 \\
\hline & & Epithelium (EC) & 0 \\
\hline \multirow{2}{*}{ Gonad } & \multirow{2}{*}{7} & Connective tissue (IH) & 1 \\
\hline & & Follicles $(\mathrm{IH})$ & 7 \\
\hline \multirow{2}{*}{ Digestive system } & \multirow{2}{*}{6} & Connective tissue (IH) & 5 \\
\hline & & Epithelium (EC) & 4 \\
\hline
\end{tabular}

489 Table 3- Tissue distribution of the parasite detected by in situ hybridisation in positive oysters; Number of positive oysters according to the organ and the tissue $(N=13)$. IH:

491 Intrahaemocytic; EC: Extracellular

492

493

494

495

496

497

498

499

500

501

502

503

504

505

506 Eurogentec).

507

508 Figures 4a, b, c and d- Hematoxylin and eosine stained sections of adult flat oysters. 
509 4a- Haemocyte infiltration in the connective tissue of gills.

$5104 \mathrm{~b}$ - Detail of 4a showing some Bonamia ostreae cells (arrows) inside the cytoplasm of 511 haemocytes. One parasite is binucleated (arrow head).

512 4c- Presence of Bonamia ostreae (arrows) in some hameocytes in the lumen of a gonadal 513 follicle.

$5144 \mathrm{~d}$ - Detail of 4c showing some Bonamia ostreae cells (arrows) inside the cytoplasm of 515 haemocytes.

516

517 Figures 5a and b- In situ hybridization assay on adult flat oysters

518 5a- Positive signal is observed in the connective tissue of gills

519 5b- Positive signal is observed in the lumen of a gonadal follicle

520

521 Figures 6a, b and c- In situ hybridization assay on larvae of flat oysters- Positive signal is 522 osberved in cells surrounding the visceral cavity.

523

524

525

526 


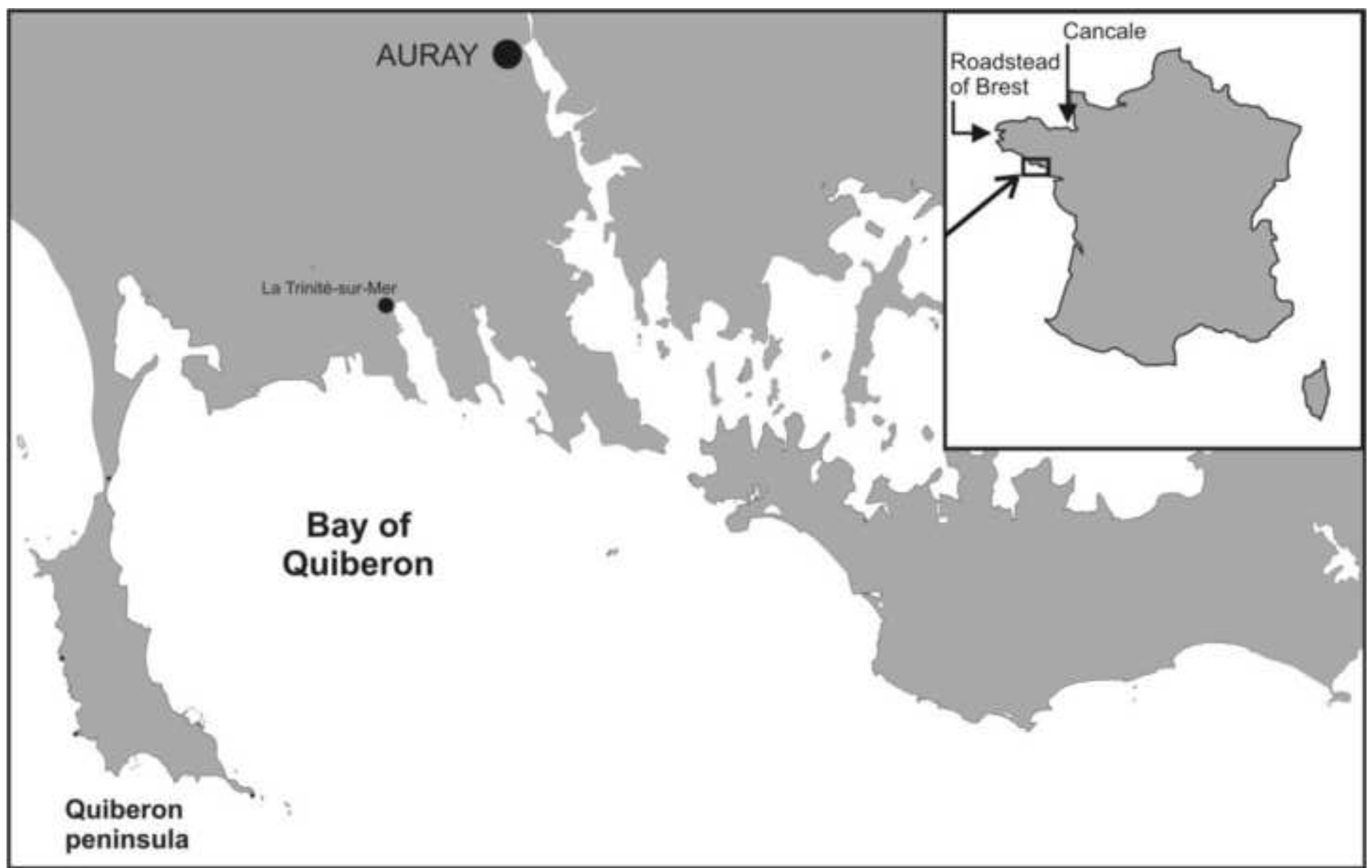


Click here to download high resolution image

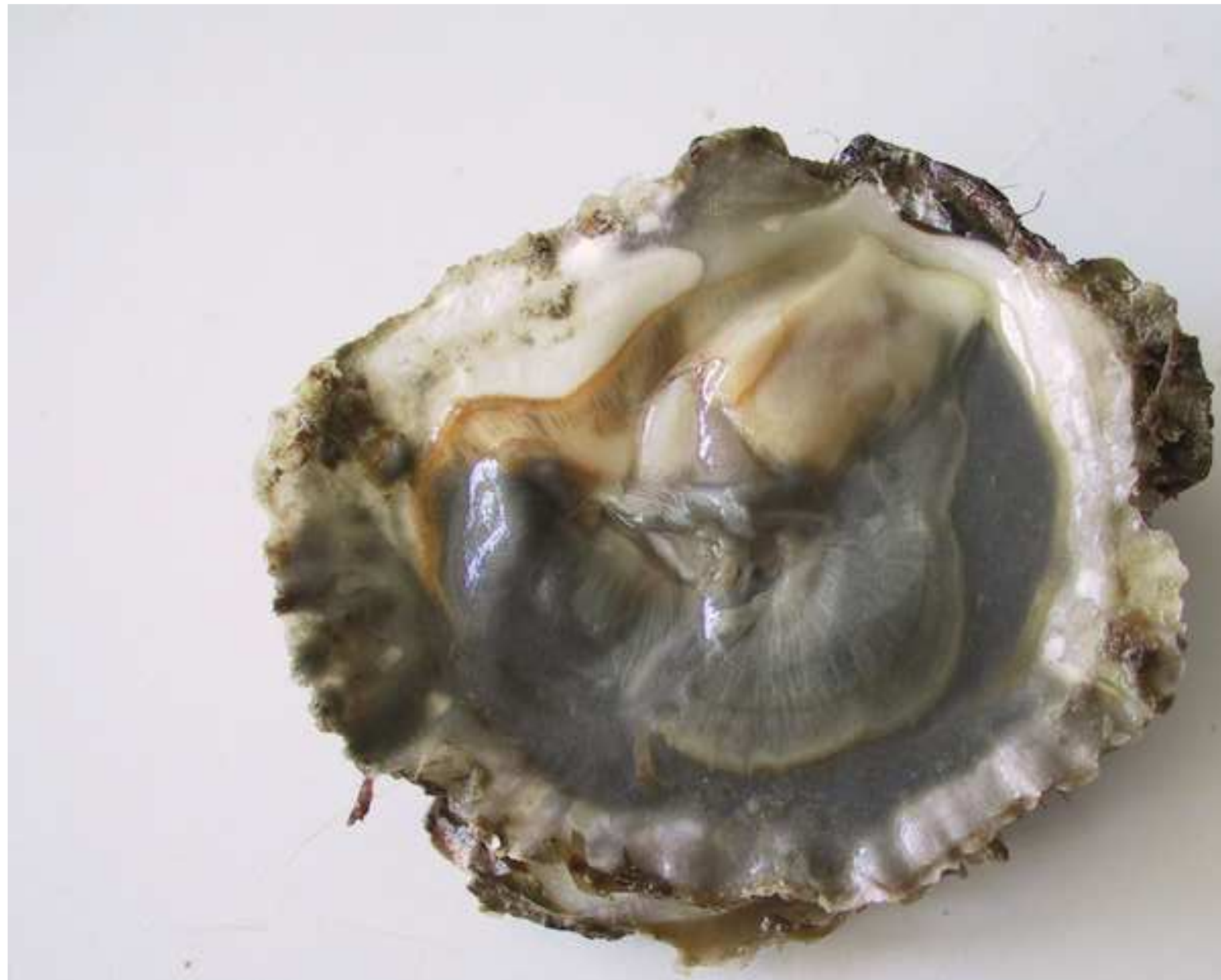


Click here to download high resolution image

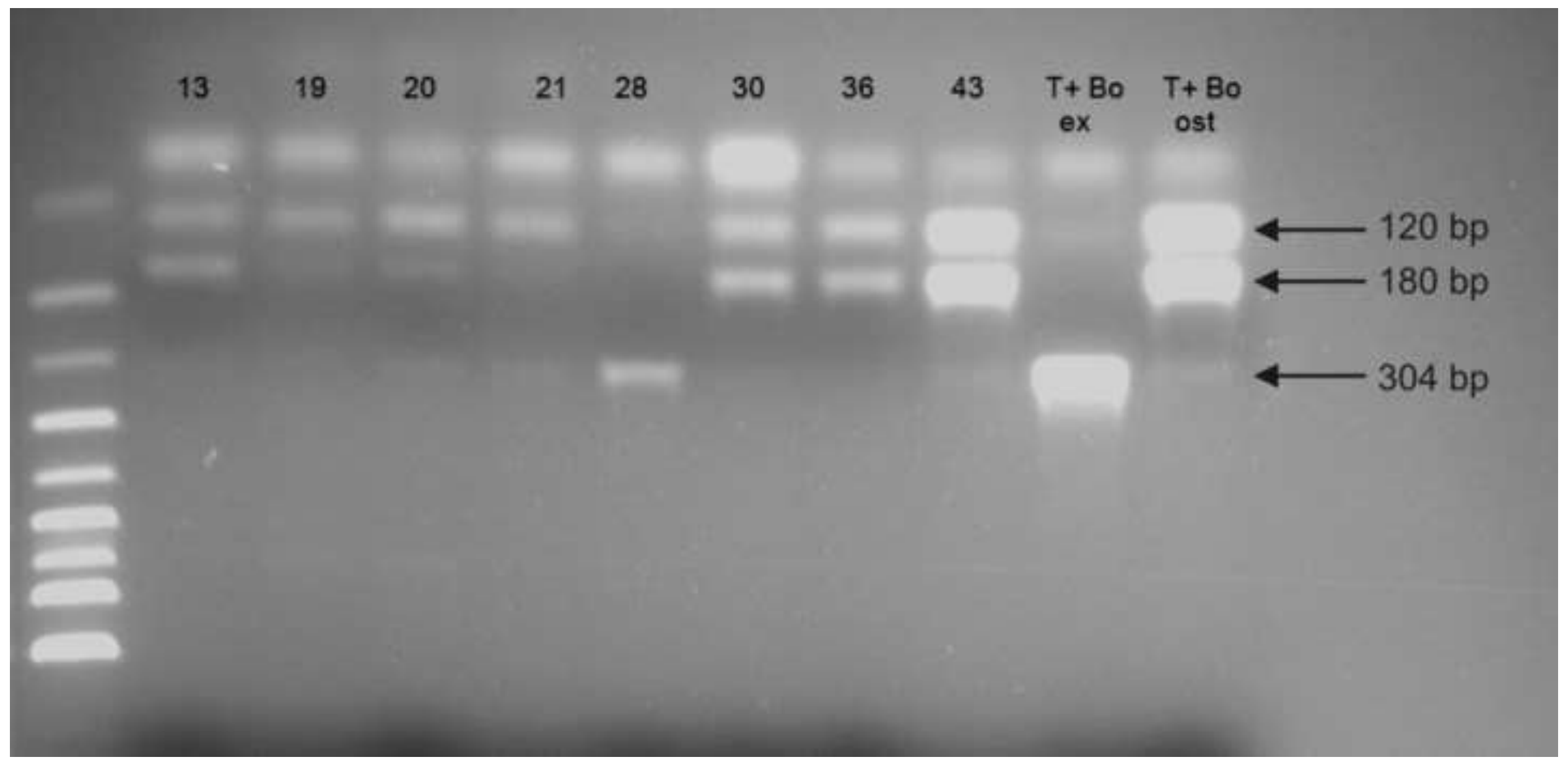


Click here to download high resolution image

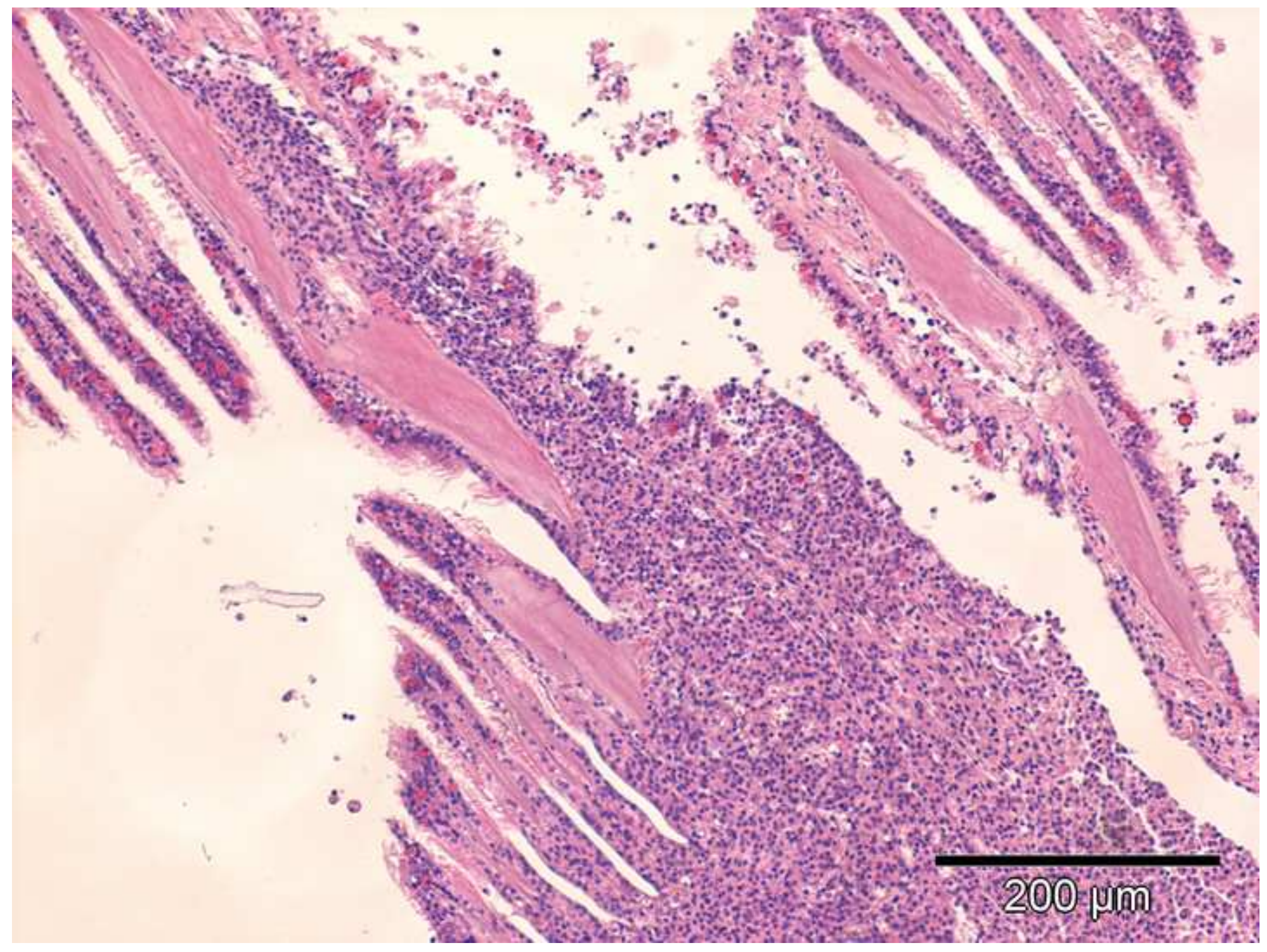


Click here to download high resolution image

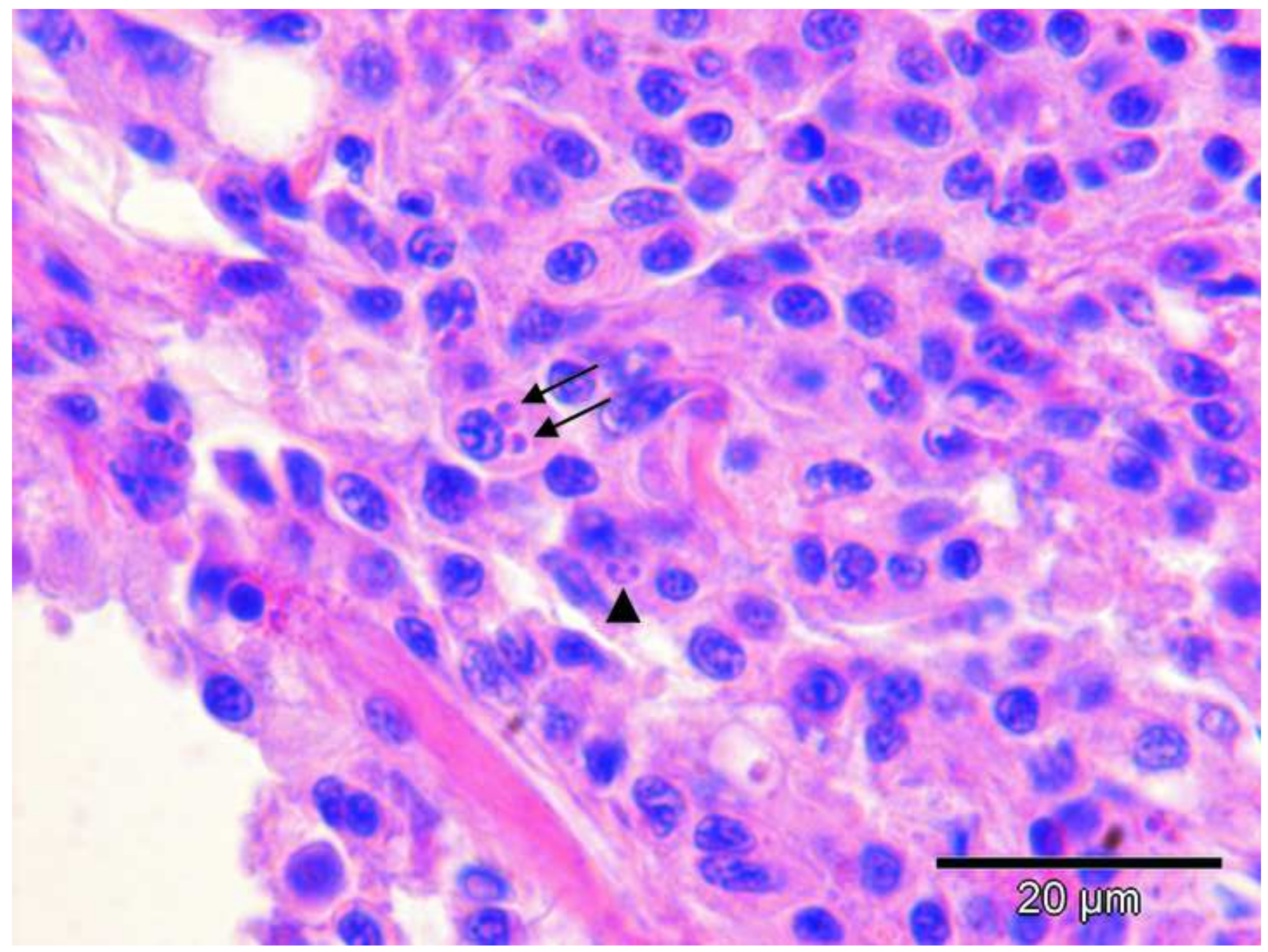


Click here to download high resolution image
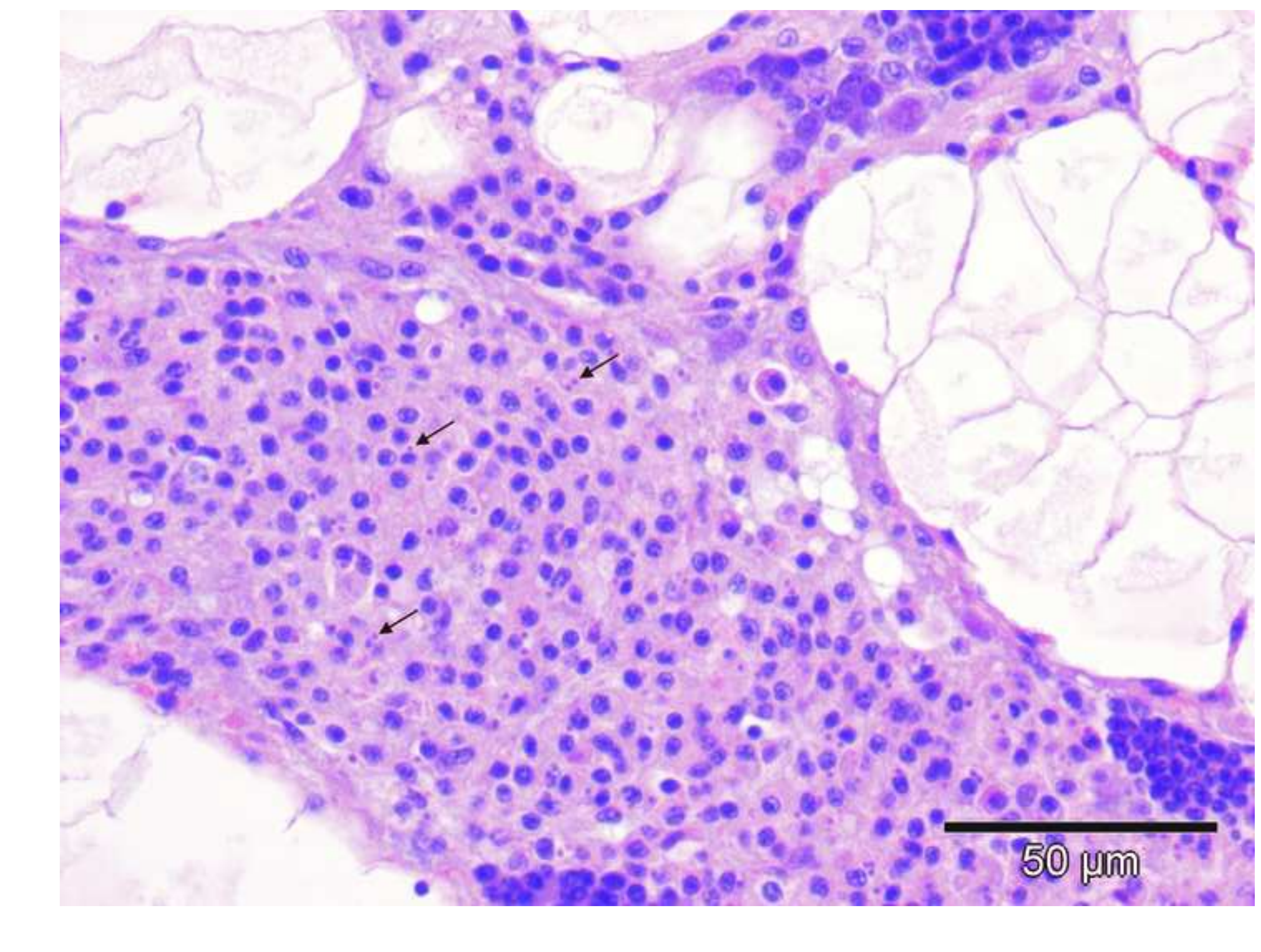

$+2$

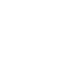

(1)

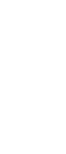


Click here to download high resolution image

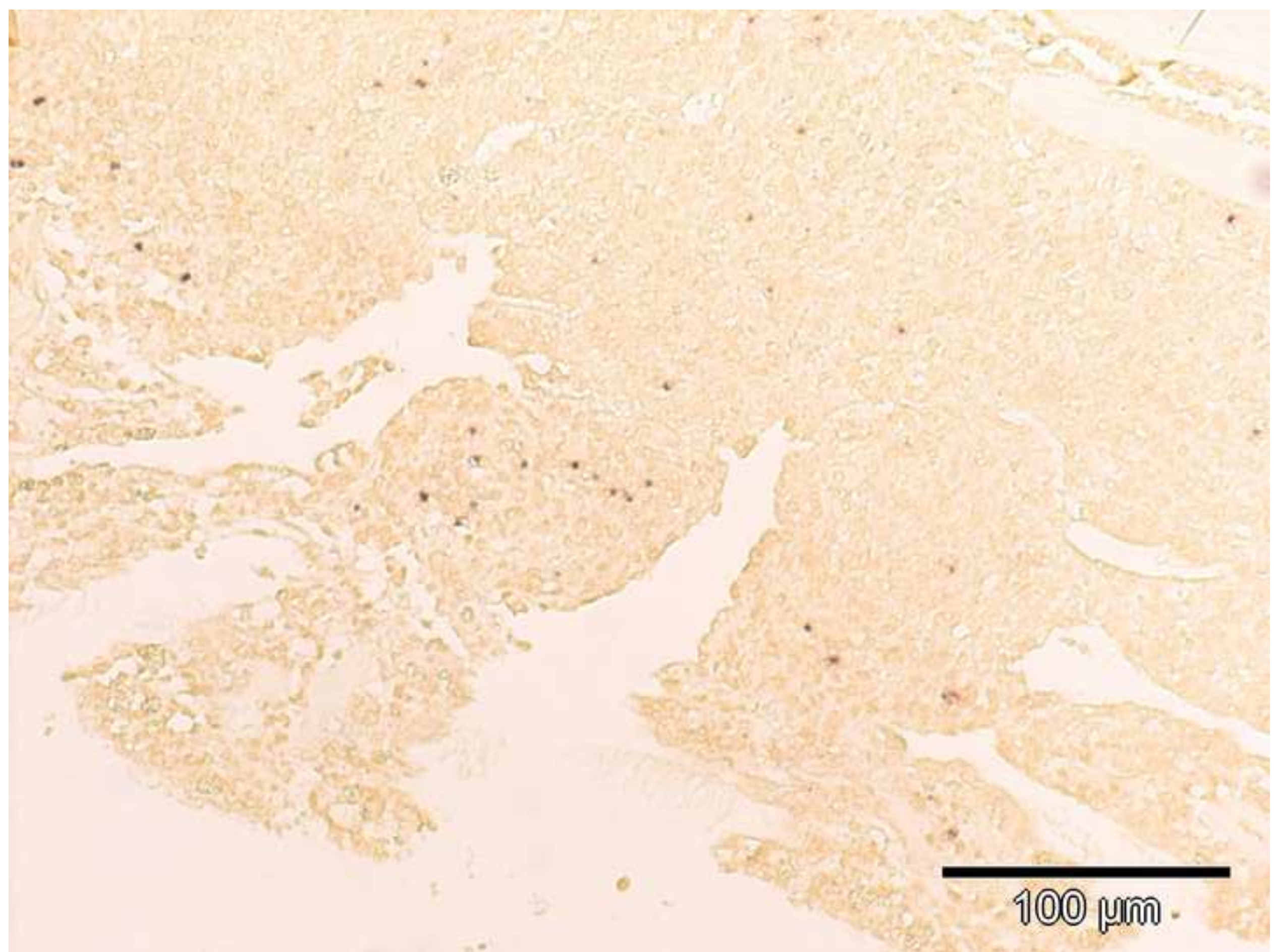


Click here to download high resolution image

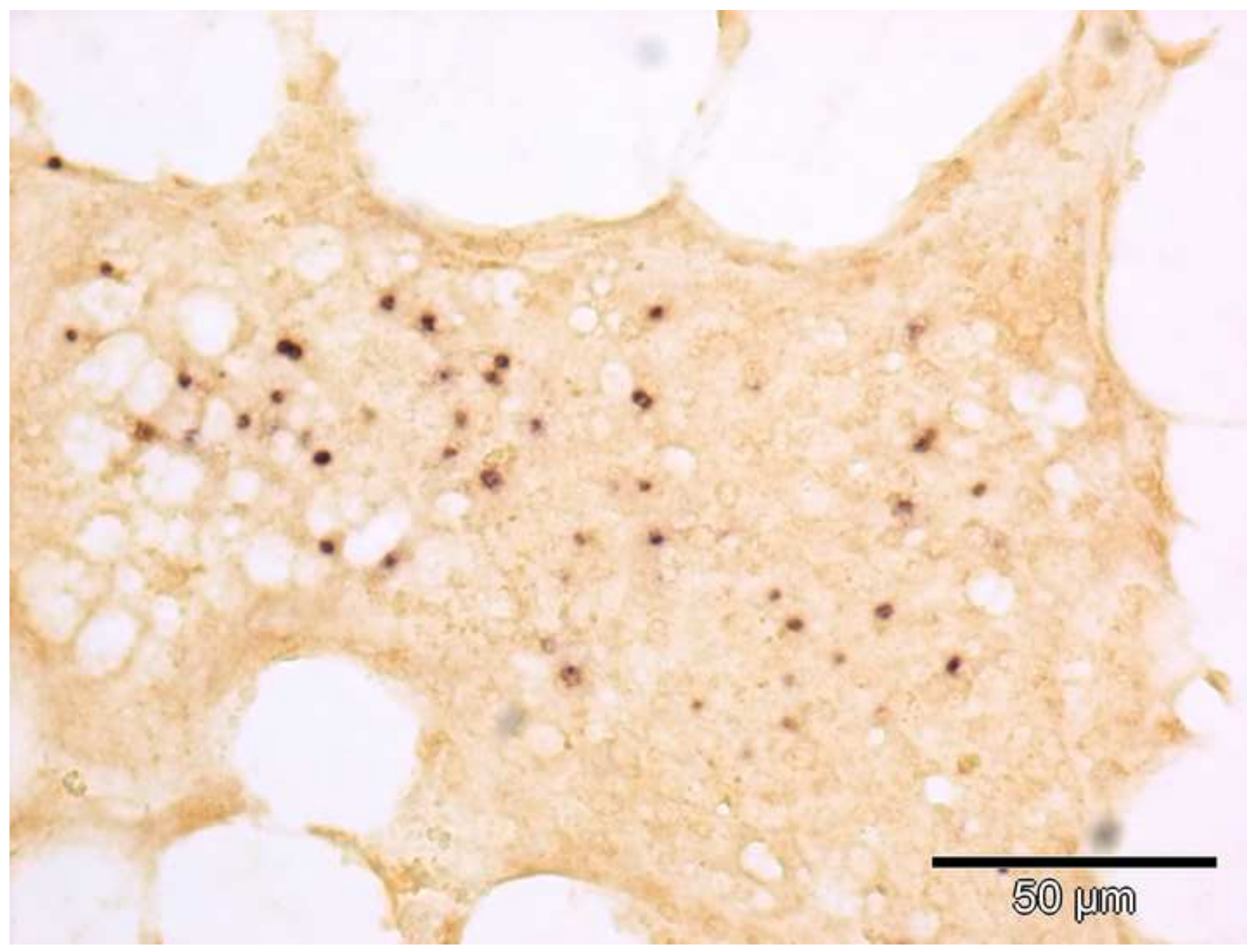


Click here to download high resolution image

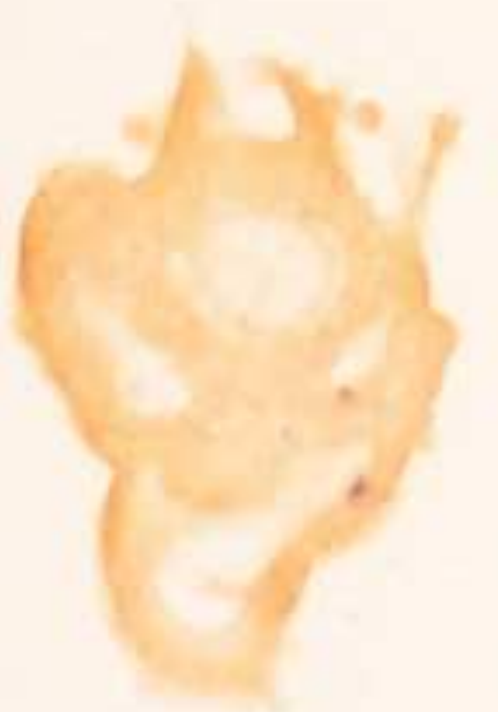

100 p)

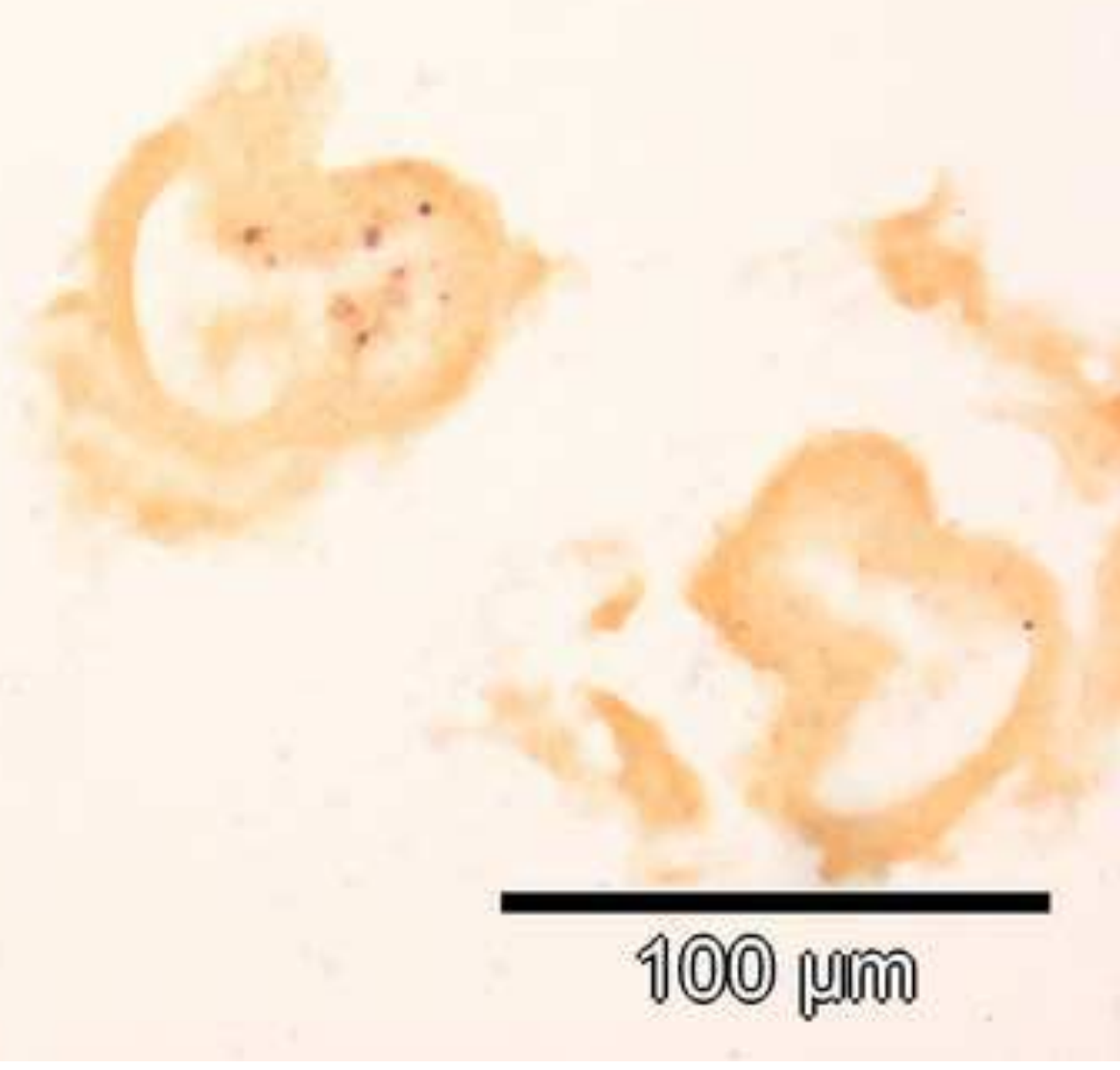


Click here to download high resolution image




Figure
Click here to download high resolution image

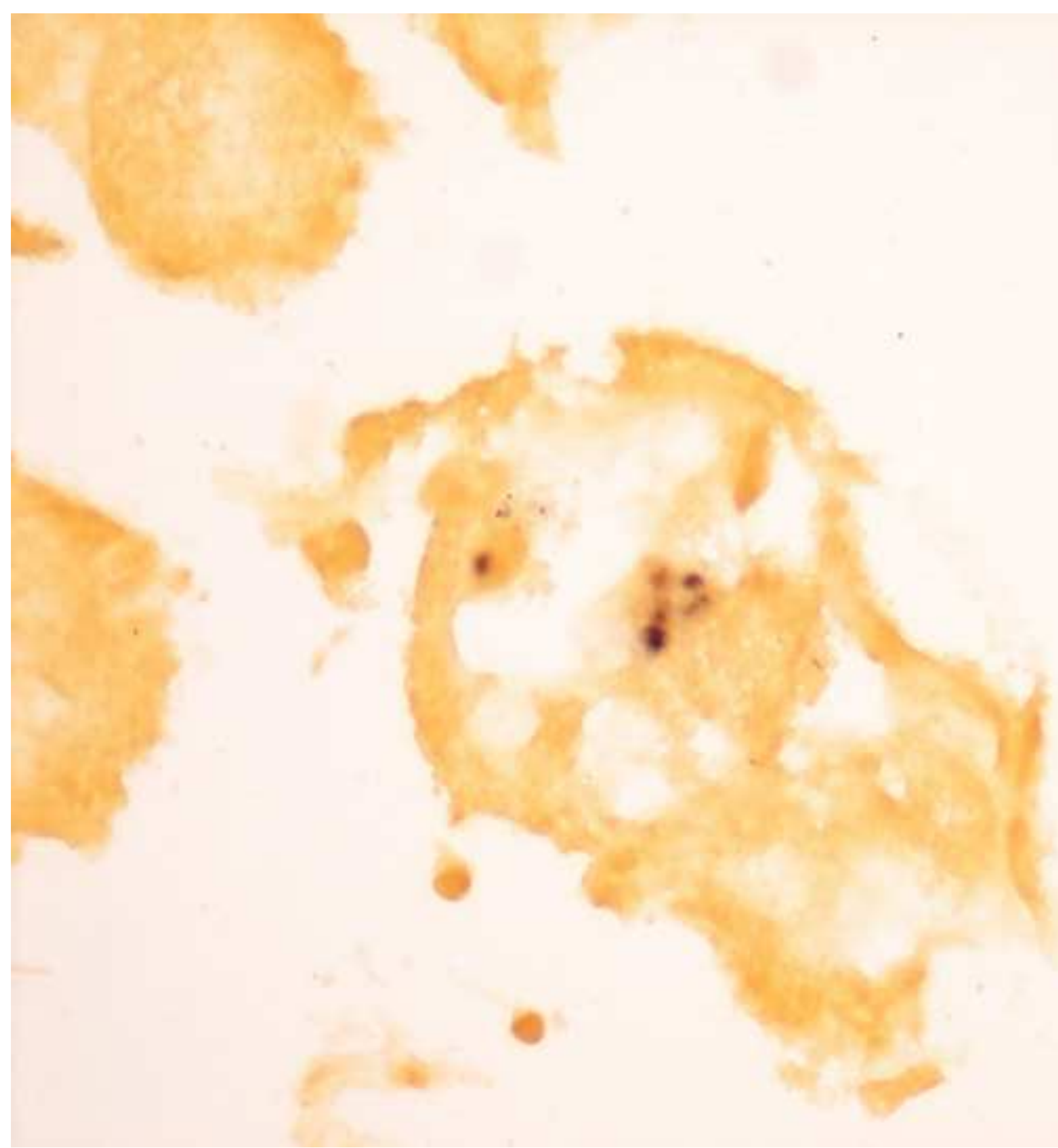

